\title{
ON THE MECHANISM OF SILICA TOXICITY
}

\author{
BY DINAH M. JAMES \\ Department of Pharmacology, Welsh National School of Medicine \\ AND J. MARKS \\ Central Tuberculosis Laboratory, Cardiff
}

Silica is chemically a substance of very low reactivity and it is widely held that the tissue damage which results from its inhalation in silicosis is due to the formation of silicic acid at the surface of the dust particles. The subject has been reviewed by King (1947). The toxicity to animals of silicic acid in its polydisperse form is well recognized but although polysilicic acid is known to react with proteins under certain conditions (Holt \& Bowcott, 1954) and to depress the activity of some enzymes (Kind, King, Pash, Roman \& Schmidt, 1954), no likely explanation has yet been found of its mode of action on living tissues.

In the work now presented, studies were made of the effect of silicic acid on tissue cultures of leucocytes, on leucocyte respiration and on the activity of a group of respiratory enzymes. One of these enzymes was inhibited in a manner which might be considered specific and to a degree which appears sufficient to account for the toxicity of silicic acid in vivo.

\section{MATERIALS AND METHODS}

Silicic acid

We have followed the majority of workers in considering the concentration of silicic acid in terms of $\mathrm{mg} . \% \mathrm{SiO}_{2}$ but it has been found more convenient to describe the results below using molarity (10 mg. $\% \mathrm{SiO}_{2}=1.67 \mathrm{~mm}$-silicic acid). Unless qualified, the concentrations stated were always those present in the completed system under examination.

Sodium silicate was prepared by fusing pure quartz with sodium carbonate. The product was dissolved by heating in distilled water in an autoclave, the volume being adjusted to give a concentration of $110 \mathrm{~mm}$. Estimations were made by the method of Straub, Straub \& Grabowski (1944). When silicic acid was needed, the silicate was neutralized with $\mathrm{HCl}$ giving a $60 \mathrm{~mm}$ solution which was adjusted to the concentration finally required within $30 \mathrm{~min}$. of the neutralization.

A note appears advisable on the physical state of the silicic acid used in the experiments to be described. It is known that when concentrated solutions of sodium silicate are neutralized, the silicic acid formed immediately begins to polymerize. Above a critical concentration, variously estimated at $1 \cdot 67-2 \cdot 67 \mathrm{~mm}$, silicic acid will remain polydisperse. Diluted to below this concentration, the polysilicic acid dissociates into the monomer, the rate and completeness of the dissociation depending on its age and history. The physical chemistry of silicic acid in this connexion has been discussed by Holt \& Osborne (1953) and by Scheel, 
Fleisher \& Klemperer (1953). In the present work studies were normally made using silicic acid diluted $20-30 \mathrm{~min}$. after its preparation to give final concentrations $1 \cdot 67,3 \cdot 33,5$ and in some instances, $10 \mathrm{~mm}$ in the systems being investigated. Polymer must have been present in the concentrations greater than $1.67 \mathrm{~mm}$ but in the latter the state of dispersion of the silicic acid appears to have depended on the experimental conditions. As described in detail below, effects were normally observed when leucocytes or enzymes were exposed to $1.67 \mathrm{~mm}$ silicic acid but they were weakened or abolished if a considerable time was allowed for preliminary dissociation. Silicic acid obtained by dialysis produced no effect. It appeared therefore that when activity of $1.67 \mathrm{~mm}$ silicic acid was noted, it was due to a residuum of undissociated polymer. Observations on the precipitation of cytochrome by silicic acid, also reported below, supported this interpretation.

\section{Leucocyte culture and respiration}

Guinea-pig leucocytes were obtained and studied in tissue culture using the methods described by Marks \& Mason (1956). They consisted mainly of macrophages, monocytes and other mononuclear cells. The leucocytes used for respiration studies were obtained similarly except for the use of Ringer's solution containing $5 \%$ guinea-pig serum and 4 units of heparin per ml. as the wash fluid. The cells were freed from this fluid by centrifugation.

Silicic acid was introduced into tissue cultures by incorporating it into the medium which was then distributed in $0.9 \mathrm{ml}$. amounts per chamber and allowed to remain $3 \mathrm{hr}$. at room temperature before the addition of the cells in $0.1 \mathrm{ml}$.

Leucocyte respiration was measured in the conventional Warburg apparatus with a gas phase of air and an incubation temperature of $37^{\circ} \mathrm{C} . \mathrm{CO}_{2}$ was absorbed by $0.2 \mathrm{ml}$. of $\mathrm{KOH}$ solution in the central cup. Leucocytes were transferred to each flask suspended in $3 \mathrm{ml}$. of a solution made up of guinea-pig serum $10 \%, \mathrm{M} / 15$

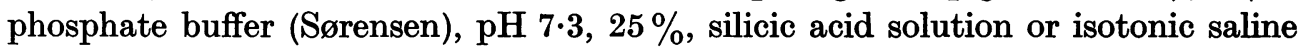
$16 \%$ and Ringer's solution $49 \%$. Their number per flask varied in different experiments between 1.0 and $1.7 \times 10^{7}$ cells. In several experiments calcium was omitted from the Ringer's solution to avoid the risk of precipitating calcium phosphate but the results were unaffected by the modification. Oxygen uptake was measured hourly for $6 \mathrm{hr}$. after a period of $30 \mathrm{~min}$. for temperature equilibration. The flasks were then disconnected, stored at $4^{\circ} \mathrm{C}$. overnight and reconnected on the following day for respiration to be measured for another $6 \mathrm{hr}$.

\section{Respiratory enzymes}

The heart muscle preparation described by Keilin \& Hartree (1938) was used since it is rich in the known enzyme components of the succinoxidase system, namely succinic dehydrogenase and cytochrome oxidase. Amounts of the suspended preparation will be expressed as the fat-free dry weight, which constituted $5 \cdot 0 \%(\mathrm{w} / \mathrm{v})$. The Warburg apparatus was again used for measuring enzyme activity but $\mathrm{KOH}$ was omitted.

Enzyme systems were assembled in a manner designed to avoid the contact of unduly high concentrations of silicic acid with the protein constituents. Water and 
buffer were added to the main compartment of the flask first, then silicic acid and finally the enzyme preparation and, when applicable, the cytochrome. The volume of these constituents totalled $3 \mathrm{ml}$., enzyme being diluted to be contained in $0.2 \mathrm{ml}$., cytochrome in $0.25 \mathrm{ml}$., when included, and silicic acid in $0.25-0.5 \mathrm{ml} .0 .2 \mathrm{ml}$. of substrate solution was added to the side-arm. After $15 \mathrm{~min}$. for temperature equilibration, substrate and enzyme were mixed and measurements of $\mathrm{O}_{2}$ uptake made at $5 \mathrm{~min}$. intervals for $30 \mathrm{~min}$. The uptake between 10 and $30 \mathrm{~min}$. was multiplied by 3 to give the hourly rate. Inhibition was determined by comparing each test with a control, which was run at the same time and identical except for the substitution of saline for silicic acid.

Cytochrome oxidase activity was measured by a method similar to that employed by Slater $(1949 a)$ except that in order to lessen the need for correcting for autoxidation, the concentration of the reducing agent, sodium ascorbate, was reduced to $0.01 \mathrm{M}$. The phosphate concentration used also differed slightly from Slater's being $0.075 \mathrm{M}$ as compared with $0.062 \mathrm{M}$. The cytochrome $c$ employed was supplied by Light and Co.

A number of observations were also made on the cytochrome oxidase system using cysteine instead of ascorbate as the reducing agent, its final concentration also being $0.01 \mathrm{M}$.

Both ascorbate and cysteine showed an $\mathrm{O}_{2}$ uptake due to autoxidation in the absence of enzyme, amounting to approximately 10 and $20 \%$ respectively of the uptakes of complete systems containing $2 \mathrm{mg}$. of enzyme and $0.75 \times 10^{-5} \mathrm{M}$-cytochrome. Allowance has not been made for autoxidation of these reducing agents in calculating the degree of inhibition observed because it is doubtful how much occurs whilst cytochrome oxidase is actually operating.

Succinoxidase activity was measured by the method described by Slater in a second paper $(1949 b)$. Observations were normally made without adding cytochrome to the system but the effect of such additions was also studied.

Succinic dehydrogenase was measured colorimetrically by the tetrazolium technique of Kun \& Abood (1949). The final volume used was $3.2 \mathrm{ml}$., of which $0.2 \mathrm{ml}$. containing the substrate was added after the remainder of the system had been incubated for $15 \mathrm{~min}$. This modification of volume and timing was made so that the results could be compared directly with those of the manometric methods. Arbitrary units of activity were used which were derived from the electrophotometer readings minus the blank reading of the system incubated without substrate. Incubation varied from $40 \mathrm{~min}$. with $16 \mathrm{mg}$. enzyme to $65 \mathrm{~min}$. with $4 \mathrm{mg}$.

The method of measuring succinic dehydrogenase activity used by Slater $(1949 b)$ was not employed in the present investigation because the methylene blue present as a hydrogen carrier was found to precipitate with silicic acid. Unlike the reaction of cytochrome with silicic acid described below, that of methylene blue was not considered germane to the present investigation because the dye is not a normal cell constituent. 


\section{RESULTS}

\section{Leucocyte cultures}

Readings were made after 3 days' incubation at $37^{\circ} \mathrm{C}$. in air plus $5 \% \mathrm{CO}_{2}$. Silicic acid in $5 \mathrm{~mm}$ concentration killed virtually every cell in the culture. The effect of $3.33 \mathrm{~mm}$ silicic acid was almost as severe, only a small proportion of the cells surviving, but in $2.5 \mathrm{~mm}$ the cell damage, although definite, was only slight. The latter concentration is probably just above the saturation point for monomeric silicic acid. No cell damage was observed in cultures containing $1.67 \mathrm{~mm}$ silicic acid. In the latter concentration the cells probably never made contact with appreciable amounts of polysilicic acid because, as noted above, $3 \mathrm{hr}$. were allowed for its dissociation before they were added. Changes in the dispersion of silicic acid during the long incubation period were thus minimized and interpretation of results so made easier.

\section{Table 1. The effect of silicic acid on leucocyte respiration}

\begin{tabular}{|c|c|c|c|c|}
\hline $\begin{array}{l}\text { Interval } \\
\text { (hr.) }\end{array}$ & Nil & $\begin{array}{c}1.67 \mathrm{~mm} \\
\left(10 \mathrm{mg} . \% \mathrm{SiO}_{2}\right)\end{array}$ & $\begin{array}{c}3.33 \mathrm{~mm} \\
\left(20 \mathrm{mg} . \% \mathrm{SiO}_{2}\right)\end{array}$ & $\begin{array}{c}5 \mathrm{~mm} \\
\left(30 \mathrm{mg} . \% \mathrm{SiO}_{2}\right)\end{array}$ \\
\hline 1 & 17 & 20 & 22 & 14 \\
\hline 2 & 10 & 7 & 7 & 5 \\
\hline 3 & 13 & 8 & 7 & 2 \\
\hline 4 & 14 & 8 & 3 & 0 \\
\hline 5 & 13 & 4 & 2 & 0 \\
\hline 6 & 9 & 3 & 1 & 0 \\
\hline Total for $6 \mathrm{hr}$. & 76 & 50 & 42 & 21 \\
\hline
\end{tabular}

The number of cells per flask was $10.8 \times 10^{6}$. Polydisperse silicic acid was considered to be present in all concentrations.

\section{Leucocyte respiration}

Silicic acid in $5 \mathrm{~mm}$ concentration severely depressed respiration within 1 or $2 \mathrm{hr}$. of mensuration beginning; after a further hour, inhibition was usually complete except for a trivial oxygen uptake on the second day. The effect of $3.33 \mathrm{~mm}$ silicic acid was almost as severe after the first hour. A $1.67 \mathrm{~mm}$ concentration resulted in a comparatively small inhibition in the first $6 \mathrm{hr}$. period, ranging from 10 to $35 \%$ in different experiments, and a considerably greater inhibition in the second period. A transient initial stimulation of respiration by the lower concentrations of silicic acid was often observed. In Table 1 are presented the results for the first $6 \mathrm{hr}$. period of a representative experiment.

In other experiments, polymer in the $\mathbf{1 . 6 7} \mathrm{mm}$ concentration of silicic acid was encouraged to dissociate by allowing it to remain either $3 \mathrm{hr}$. or overnight in 0.86 of the final fluid volume, i.e. at $1.94 \mathrm{~mm}$ concentration, before adding the cells and serum in 0.14 of the volume. In neither case was more than a trivial depression of respiration observed, suggesting that, as in leucocyte cultures, dissociation of the polymerized form of silicic acid was accompanied by a loss of toxicity. 


\section{Enzyme studies}

The Keilin and Hartree heart-muscle preparation was used for all three enzyme systems. Two separate preparations were made during the course of the investigation. They were of comparable activity and gave the same fat-free dry weight. Protocols of representative experiments on each enzyme system are given in Table 2. Otherwise it has been found more convenient to present the results in terms of the percentage inhibition of enzyme activity.

Table 2. The effect of silicic acid on the activity of cytochrome oxidase, succinoxidase and succinic dehydrogenase in representative experiments

\begin{tabular}{|c|c|c|c|c|c|c|c|}
\hline \multirow{2}{*}{$\begin{array}{l}\text { Enzyme and quantity } \\
\text { (in } 3.2 \mathrm{ml} \text {.) }\end{array}$} & \multirow{2}{*}{$\begin{array}{l}\text { Added } \\
\text { cyto- } \\
\text { chrome } \\
\times 10^{-5} \mathrm{M}\end{array}$} & \multirow{2}{*}{$\begin{array}{l}\text { Units of } \\
\text { activity }\end{array}$} & \multicolumn{5}{|c|}{$\begin{array}{l}\text { Enzyme activity with given } \\
\text { silicic acid concentrations }\end{array}$} \\
\hline & & & Nil & $1.67 \mathrm{~mm}$ & $3.33 \mathrm{~mm}$ & $5 \mathrm{~mm}$ & $10 \mathrm{~mm}$ \\
\hline Cytochrome oxidase (2 mg.) & 0.75 & $\mu \mathrm{l} . \mathrm{O}_{2} / \mathrm{hr}$ & 150 & 99 & 63 & 48 & - \\
\hline Cytochrome oxidase (2 mg.) & $1 \cdot 50$ & $\mu \mathrm{l} . \mathrm{O}_{2} / \mathrm{hr}$ & 174 & 132 & 84 & 72 & - \\
\hline Succinoxidase (2 mg.) & Nil & $\mu \mathrm{l} . \mathrm{O}_{2} / \mathrm{hr}$ & 306 & 261 & 219 & 159 & 93 \\
\hline $\begin{array}{l}\text { Succinic dehydrogenase } \\
\text { (4 mg.) }\end{array}$ & Nil & $\begin{array}{l}\text { Photometer } \\
\text { units } / \mathrm{hr} \text {. }\end{array}$ & $18 \cdot 1$ & - & - & $13 \cdot 6$ & $7 \cdot 6$ \\
\hline
\end{tabular}

The reducing agent used with cytochrome oxidase was $0.01 \mathrm{M}$-ascorbate.

\section{Cytochrome oxidase}

The system most susceptible to silicic acid was cytochrome oxidase. Observations made in the course of eleven experiments may be summarized as follows:

$\begin{array}{cccc}\begin{array}{c}\text { Added } \\ \text { cytochrome }\end{array} & \begin{array}{c}\text { Inhibition of cytochrome oxidase }(2 \mathrm{mg} . \text { in } 3.2 \\ \text { by given silicic acid concentrations }\end{array} \\ \times 10^{-5} \mathrm{M} & \begin{array}{c}1.67 \mathrm{mM} \\ (\%)\end{array} & \begin{array}{c}3.33 \mathrm{mM} \\ (\%)\end{array} & \begin{array}{c}5 \mathrm{mM} \\ (\%)\end{array} \\ 0.75 & 37(6) & 57(4) & 71(8) \\ 1.50 & 23(4) & 46(4) & 64(9) \\ 3.0 & - & - & 52(2) \\ 6.0 & - & - & 35(3)\end{array}$

The percentages given are means, the number of individual observations being shown in parenthesis. It is apparent that the activity of cytochrome oxidase was protected to a considerable extent against the effect of silicic acid by increases in cytochrome concentration. Over the range indicated, cytochrome increments also augmented the activity of the enzyme itself, controls with $6.0 \times 10^{-5} \mathrm{M}$ added cytochrome being nearly three times as active as those with $0.75 \times 10^{-5} \mathrm{M}$.

Cysteine proved less satisfactory than ascorbate as a reducing agent in the cytochrome oxidase system, the results obtained being more variable. This defect may have been related to its relative insolubility at $\mathrm{pH} \mathbf{7 \cdot 3}$ or to its high autoxidation rate. The mean inhibition by $5 \mathrm{~mm}$ silicic acid of $2 \mathrm{mg}$. enzyme in $3.2 \mathrm{ml}$. with $0.75 \times 10^{-5} \mathrm{M}$ cytochrome was $44 \%$ in six experiments. If an allowance had been made for autoxidation the mean inhibition would have been $59 \%$. 


\section{Succinoxidase}

The activity of succinoxidase ( $2 \mathrm{mg}$. in $3.2 \mathrm{ml}$.) proved to be considerably less susceptible to silicic acid than that of cytochrome oxidase and therefore the effect of a higher silicic acid concentration, $10 \mathrm{~mm}$, was also examined. Observations made in the course of ten experiments may be summarized as follows:

Inhibition of succinoxidase ( $2 \mathrm{mg}$. in $3.2 \mathrm{ml}$.) by given silicic acid concentrations (no added cytochrome):

$\begin{array}{cccc}1.67 \mathrm{mM} & 3.33 \mathrm{mM} & 5 \mathrm{~mm} & 10 \mathrm{~mm} \\ 10 \%(5) & 29 \%(5) & 43 \%(9) & 65 \%(6)\end{array}$

Cytochrome was not added to the system in these ten experiments. In other experiments its addition was found to protect succinoxidase against silicic acid as in the case of cytochrome oxidase but not to augment the activity of the enzyme itself. Details of a representative experiment on succinoxidase are shown in Table 2.

\section{Succinic dehydrogenase}

In order to obtain substantial readings when succinic dehydrogenase activity was estimated, somewhat higher concentrations of enzyme were needed than those optimal for the other two enzyme systems. Using $4 \mathrm{mg}$. of enzyme in $3.2 \mathrm{ml}$., the mean inhibition of succinic dehydrogenase activity in four experiments by $5 \mathrm{~mm}$ silicic acid was $28 \%$ and by $10 \mathrm{~mm}$ silicic acid $53 \%$; in preliminary experiments with $2.5 \mathrm{~mm}$ silicic acid, no inhibition was seen. To determine how far these results

Table 3. The effect of varying enzyme concentration on inhibition by silicic acid

\begin{tabular}{|c|c|c|c|c|c|c|c|c|c|}
\hline \multirow[b]{2}{*}{$\begin{array}{l}\text { Enzyme } \\
\text { system }\end{array}$} & \multirow{2}{*}{$\begin{array}{l}\text { Added } \\
\text { cyto- } \\
\text { chrome } \\
\times 10^{-5} \mathrm{M}\end{array}$} & \multirow{2}{*}{$\begin{array}{l}\text { Silicic } \\
\text { acid } \\
\text { concen- } \\
\text { tration } \\
\text { (mM) }\end{array}$} & \multirow{2}{*}{$\begin{array}{l}\text { No. of } \\
\text { experi- } \\
\text { ments }\end{array}$} & \multicolumn{6}{|c|}{$\begin{array}{l}\text { Mean inhibition with given } \\
\text { concentrations of enzyme } \\
\text { (mg. in } 3.2 \text { ml.) }\end{array}$} \\
\hline & & & & $\begin{array}{c}0.5 \\
(\%)\end{array}$ & $\begin{array}{c}1 \\
(\%)\end{array}$ & $\begin{array}{c}2 \\
(\%)\end{array}$ & $\begin{array}{c}4 \\
(\%)\end{array}$ & $\begin{array}{c}8 \\
(\%)\end{array}$ & $\begin{array}{l}16 \\
(\%)\end{array}$ \\
\hline Cytochrome oxidase & $0 \cdot 75$ & 5 & 2 & - & 71 & 72 & 64 & 一 & - \\
\hline Cytochrome oxidase & $1 \cdot 50$ & 5 & 4 & - & 67 & 68 & 63 & - & - \\
\hline Succinoxidase & Nil & $\mathbf{5}$ & $6^{*}$ & 90 & 69 & 45 & 14 & - & - \\
\hline $\begin{array}{l}\text { Succinic } \\
\text { dehydrogenase }\end{array}$ & Nil & 5 & 4 & - & - & - & 28 & $\mathbf{5}$ & 5 \\
\hline Cytochrome oxidase & 1.50 & 10 & 2 & - & 82 & 86 & 81 & - & 一 \\
\hline Succinic & Nil & 10 & 4 & - & - & - & 53 & 23 & 8 \\
\hline
\end{tabular}

dehydrogenase

* Compounded of four experiments at 1,2 and $4 \mathrm{mg}$. levels and two experiments at 0.5, 1 and $2 \mathrm{mg}$. The reducing agent for cytochrome oxidase was ascorbate.

could be compared with those cited above for cytochrome oxidase and succinoxidase, a study was made of the effect of varying the enzyme concentration in each system. The results, which are presented in Table 3, are of interest in that they show a difference between the effect on cytochrome oxidase and on the other systems. In the latter, inhibition by silicic acid decreased as the enzyme concentration increased. In contrast, the degree of inhibition of cytochrome oxidase was unaffected by changes in enzyme concentration over the range studied. 


\section{Observations on cytochrome c}

To determine whether the protective effect of cytochrome against silicic acid was merely due to the introduction into the system of extra protein, the activity of haemoglobin and serum albumin in this respect was investigated. The system employed was succinoxidase ( $2 \mathrm{mg}$. in $3.2 \mathrm{ml}$.) without added cytochrome. It was found that amounts of haemoglobin and serum albumin equivalent in weight to $6.0 \times 10^{-5} \mathrm{M}$ cytochrome left unchanged the inhibitory effect of $5 \mathrm{~mm}$ silicic acid. Protamine was also investigated but it precipitated at $\mathrm{pH} 7 \cdot 3$ and proved inhibitory itself.

It was noted that pink floccules appeared in systems containing cytochrome and silicic acid, which recalled the observations of Holt \& Bowcott (1954) on the effect of silicic acid on proteins. Their observations on the precipitation of haemoglobin and albumin by silicic acid at $\mathrm{pH}$ levels in the neighbourhood of the isoelectric points were confirmed and extended to cytochrome. Using citric-phosphate, phosphate and glycine- $\mathrm{NaOH}$ buffers over the $\mathrm{pH}$ range 2-12 it was found that precipitation of cytochrome by silicic acid was maximum in the $\mathrm{pH}$ range 6-9 as

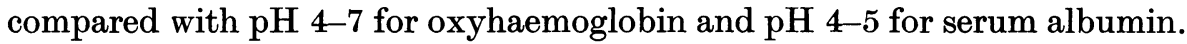

\section{The effects of $1.67 \mathrm{~mm}$ silicic acid}

A special study was made of the effects of $1.67 \mathrm{~mm}$ silicic acid since its inhibition of enzymes and leucocyte respiration as recorded above was unforeseen. It had been expected that silicic acid diluted to such a low concentration soon after its formation would dissociate into biologically inactive monomer. Leucocyte respiration and cytochrome oxidase in the presence of $0.75 \times 10^{-5} \mathrm{M}$ added cytochrome, having been found the most sensitive systems, were chosen for the examination. It was found that if the silicic acid were allowed to dissociate in the remainder of the systems before the cells or protein components were added in minimum volumes, its effect became progressively weaker as the interval was increased. When dialysates containing $2.25 \mathrm{~mm}$ silicic acid were incorporated in the cytochrome oxidase system to give a $1.67 \mathrm{~mm}$ concentration, no depression of enzyme activity was observed. Each dialysate was prepared by dialysing $4 \mathrm{ml}$. of freshly prepared $60 \mathrm{~mm}$ silicic acid against $10 \mathrm{ml}$. of distilled water for 3 days. Similar dialysates with Ringer-phosphate substituted for water had no effect on leucocyte respiration but their silica content was not estimated.

The effect of $1.67 \mathrm{~mm}$ silicic acid on cytochrome was also studied. A $30 \mathrm{~mm}$ solution of silicic acid was prepared, allowed $30 \mathrm{~min}$. for polymerization and then diluted to $1.67 \mathrm{~mm}$ in $\mathrm{M} / 15$ phosphate buffer, $\mathrm{pH} 7 \cdot 3$. At hourly intervals for $5 \mathrm{hr}$. and again next morning, $0.9 \mathrm{ml}$. samples were removed and each mixed with $0.1 \mathrm{ml}$. of $24 \times 10^{-5} \mathrm{M}$ cytochrome. Precipitation was observed on each occasion, the degree lessening as the interval allowed for dissociation increased; it was delayed in its appearance and very faint in the overnight test. The reaction of $1.67 \mathrm{~mm}$ silicic acid with cytochrome thus appeared to parallel its action on cytochrome oxidase and leucocyte respiration. Succinoxidase and succinic dehydrogenase 
were not examined in similar conditions because their susceptibility to low concentrations of silicic acid was so slight.

The precipitation of cytochrome by $1.67 \mathrm{~mm}$ silicic acid in $\mathrm{M} / 15$ phosphate buffer, $\mathrm{pH} 7 \cdot 3$, was reproduced, at the same $\mathrm{pH}$, in borate, barbitone and bicarbonate$\mathrm{CO}_{2}$ buffer systems and in $0.9 \% \mathrm{NaCl}$ but not in water. It appeared therefore to require the presence of salts. Cytochrome was precipitated in water by silicic acid in $3.33 \mathrm{~mm}$ or greater concentrations but these contained appreciable amounts of salt themselves.

To attain the concentration of $1.67 \mathrm{~mm}$ silicic acid without passing through the polymer stage, $0.3 \mathrm{ml}$. of $110 \mathrm{~mm}$ sodium silicate was diluted with $19.25 \mathrm{ml}$. of $\mathrm{m} / \mathbf{1 5}$ phosphate buffer, $\mathrm{pH} \mathbf{7 \cdot 3}$, and neutralized with the calculated amount of $\mathrm{HCl}$ in $0.25 \mathrm{ml}$. The resulting $1.67 \mathrm{~mm}$ solution of silicic acid gave no precipitate with cytochrome, suggesting that polymerized silicic acid was essential for the reaction.

\section{DISCUSSION}

The results of the present study of silicic acid toxicity agree with those obtained by previous workers in vivo in incriminating the polymerized form. A close correspondence was found between the susceptibility to silicic acid of living leucocytes and of cytochrome oxidase, a respiratory enzyme which plays an essential role in cell metabolism. Moreover, the effect demonstrated on cytochrome oxidase appears to have been specific in that its substrate cytochrome $c$, rather than the enzyme protein, was the point of attack, for the degree of inhibition produced by a given concentration of silicic acid was lessened by an increase in cytochrome concentration, but not by an increase in enzyme. The two other respiratory enzyme systems studied, succinoxidase and succinic dehydrogenase, differed from cytochrome oxidase in that they were far less susceptible to low concentrations of silicic acid and manifested an inverse relationship between enzyme concentration and degree of inhibition, suggesting a direct action of the silicic acid on the enzyme.

The precipitation of cytochrome $c$ by low concentrations of polysilicic acid at physiological $\mathrm{pH}$ levels as described above may prove to be the basis of the biological activity of silica. The particular susceptibility of cytochromein this respect would appear to be related to the high $\mathrm{pH}$ of its isoelectric point. Other cell proteins may well be unaffected by silicic acid because their isoelectric points lie in a more acid range.

The Keilin and Hartree preparation used in the present work is composed of cytoplasmic particles which contain a bound form of cytochrome apparently available to the complete succinoxidase system (cytochrome oxidase and succinic dehydrogenase acting together) but not effective as a substrate for cytochrome oxidase acting alone. The bound cytochrome appears to have been inaccessible to silicic acid in the conditions employed in the present work for otherwise the susceptibility of succinoxidase would have been at least as great as that of cytochrome oxidase which is one of its components. It does not follow that in the living cell the cytochrome connected with succinoxidase would enjoy a similar immunity because the time available for the diffusion of silicic acid would be 
greater and access might be less difficult. Whether this is the case or not, cytochrome oxidase is known to be concerned in the oxidation of many different substances and its inactivation in respect of these would be at least as important as in respect of succinate metabolism.

\section{SUMMARY}

Silicic acid in its polymerized form is toxic to leucocytes in tissue culture and depresses leucocyte respiration, effects which appear to be paralleled by its inhibition of the cytochrome oxidase enzyme system. There is evidence that silicic acid acts on this system by combining with and inactivating cytochrome $c$ and it is suggested that its effect in vivo may have a similar basis. The inhibitory effect of silicic acid on the two other respiratory enzyme systems studied is considerably less intense and probably non-specific.

We are indebted to Miss M. A. Mason for preparing our sodium silicate and for several silica estimations.

\section{REFERENCES}

Holt, P. F. \& Bowcott, J. E. L. (1954). Biochem. J. 57, 471.

Holt, P. F. \& Osborne, S. G. (1953). Brit. J. indust. Med. 10, 152.

Keinin, D. \& Hartree, E. F. (1938). Proc. roy. Soc. B, 125, 171.

Kind, P. R. N., King, E. J., PASH, V., Roman, W. \& Schmidt, E. (1954). Biochem. J. 56, xlv. KING, E. J. (1947). Occup. Med. 4, 26.

Kun, E. \& Aвood, L. G. (1949). Science, 109, 144.

Marks, J. \& Mason, M. A. (1956). Brit. J. indust. Med. (in the Press).

Scheel, L. D., Fleisher, E. \& Kremperer, F. W. (1953). Arch. indust. Hyg. occup. Med. $8,564$.

Slater, E. C. (1949a). Biochem. J. 44, 305.

Slater, E. C. $(1949 b)$. Biochem. J. 45, 1.

Straub, F., StraUb, G. \& Grabowski, H. A. (1944). Indust. Engng. Chem. (Anal. ed.), 16, 574. 